\title{
DETEKSI Salmonella enterica serovar Typhimurium DALAM PRODUK PANGAN SIAP SAJI MENGGUNAKAN METODE PCR, MELT CURVE, DAN ANALISIS HRM
}

\author{
Sitti Nurhamidah, M. Natsir Djide, Rudi Arfiansyah, Firzan Nainu \\ Fakultas Farmasi, Universitas Hasanuddin, Makassar
}

Kata Kunci :

Salmonella enterica serovar Typhimurium, Pangan olahan, PCR, Melt Curve, HRM

\begin{abstract}
ABSTRAK
Metode kultur konvensional membutuhkan waktu pengerjaan yang lama, dan sumber daya laboratorium yang besar. Olehnya itu, telah dikembangkan metode berbasis DNA dalam pengujian mikrobiologi. Tujuan penelitian ini adalah untuk menentukan metode yang tepat, dari berbagai metode berbasis DNA, dalam mendeteksi Salmonella enterica serovar Typhimurium pada produk pangan siap saji. Metode yang digunakan dalam penelitian ini adalah PCR, Melt Curve, dan Analisis HRM (High Resolution Melting). Dua gen yang digunakan sebagai target analisis molekuler dalam penelitian ini adalah invA dan fliC. Pengujian dilakukan terhadap tiga jenis sampel pangan siap saji, yaitu olahan daging, olahan unggas, dan salad buah. Hasil penelitian menunjukkan bahwa metode PCR dan Melt Curve dapat mendeteksi Salmonella enterica serovar Typhimurium menggunakan primer yang mengamplifikasi sekuens spesifik pada gen fliC. Walaupun demikian, sensitivitas yang lebih baik ditunjukkan oleh metode real-time PCR dengan nilai LOD 0,5 pg. Lebih lanjut, metode analisis HRM terbukti mampu mendeteksi Salmonella enterica serovar Typhimurium dan membedakannya dari serovar Salmonella yang lain, meskipun menggunakan primer invA yang kurang spesifik.
\end{abstract}

\section{PENDAHULUAN}

Kasus keracunan makanan telah banyak terjadi di dunia ini, bahkan di negara maju sekalipun. Di Amerika setiap tahun diperkirakan terjadi 48 juta kasus keracunan yang mengakibatkan sekitar 128.000 orang dirawat di rumah sakit dan sekitar 3000 orang meninggal dunia (1). Selama tahun 2015 Badan POM telah mencatat 61 kejadian luar biasa (KLB) keracunan pangan yang berasal dari 34 Propinsi. Dilaporkan jumlah orang yang terpapar sebanyak 8.263 orang, sedangkan kasus KLB keracunan pangan (case) yang dilaporkan sebanyak 2.251 orang sakit dan 3 orang meninggal dunia (2).

Berdasarkan data dari WHO tahun 2018, Salmonella merupakan penyebab tertinggi kasus keracunan makanan di seluruh dunia. Salmonella umumnya menginfeksi manusia melalui konsumsi makanan yang terkontaminasi terutama berasal dari daging, unggas, telur, dan susu (3). Infeksi yang disebabkan oleh Salmonella merupakan masalah kesehatan yang sangat signifikan. Penelitian yang dilakukan oleh WHO terhadap keracunan pangan di dunia, menunjukkan bahwa non thyphoidal serovars (NTS) telah memberikan pengaruh yang paling besar terhadap masalah kesehatan di Afrika, Asia Tenggara, dan Eropa Timur. Keracunan yang disebabkan oleh non thyphoidal serovars, termasuk didalamnya adalah Salmonella enterica serovar Typhimurium dan Salmonella enterica serovar Enteritidis, diperkirakan terjadi sebanyak 93,8 juta diseluruh dunia dengan tingkat kematian diperkirakan terjadi pada 155.000 kasus (4).
Salah satu kendala pengujian mikrobiologi bakteri patogen pada makanan adalah komposisi makanan dan matriks yang kompleks (5). Metode kultur konvensional untuk mendeteksi Salmonella pada makanan, telah digunakan secara luas. Akan tetapi metode tersebut membutuhkan waktu pengerjaan yang cukup lama (3-5 hari) dan sumber daya laboratorium yang besar.

Pengujian PCR (Polymerase Chain Reaction) yang cepat dan akurat sangat tepat diterapkan dalam pengujian mikrobiologi (6). PCR telah mengalami perkembangan dengan adanya instrumen realtime PCR, yang dapat memberikan hasil yang lebih cepat dibandingkan dengan PCR konvensional (5). Metode baru berbasis real-time PCR yang belum banyak digunakan dalam deteksi bakteri patogen adalah high-resolution melting (HRM) analysis. Salah satu penelitian yang menggunakan metode HRM dilakukan oleh Bratchikov dkk. (7) bertujuan untuk menentukan serotipe spesies Salmonella. Metode ini memberikan hasil yang cepat, dan mudah untuk diinterpretasi. Akan tetapi metode dalam penelitian tersebut belum diaplikasikan pada produk pangan. Olehnya itu perlu dilakukan penelitian lebih lanjut. Metode berbasis DNA diharapkan dapat memberikan hasil pengujian yang lebih cepat dan akurat dalam penanganan kasus keracunan. 


\section{METODE PENELITIAN}

\section{Alat dan bahan}

Alat-alat yang digunakan adalah Sentrifuge (5430R, Eppendorf), real time PCR 7500 (Applied Biosystem), real time PCR Rotor Gene Q (Qiagen), Nanospektrofotometer (NanoDrop 2000c, Thermo Scientific), Elektroforesis gel agarosa (PowerPac ${ }^{\mathrm{TM}}$ Basic, Biorad), Dokumentasi gel (GelDoc ${ }^{\mathrm{TM}}$ XRT Imaging System, Biorad).

Bahan-bahan yang digunakan adalah sampel pangan siap saji dengan tiga matriks yang berbeda, bakteri uji target Salmonella enterica serovar Typhimurium ATCC 14028, bakteri uji non target Salmonella enterica serovar Enteritidis ATCC 13076, Escherichia coli ATCC 25922, Staphylococcus aureus ATCC 25922, Listeria monocytogenes ATCC 7644, Shigella sonnei ATCC 9290, dan Bacillus cereus ATCC 6633. Media BPLS agar (Merck), Media BPW (Oxoid), Media PCA (Merck), Media BHIB (Merck), $\mathrm{NaCl}$ 0,9\% (Otsuka), Wizard ${ }^{\circledR}$ Genomic DNA Purification Kit (Promega), GoTaq ${ }^{\circledR}$ Green Master Mix (Promega), Power up SYBR Green (Applied Biosystems), Agarose-Biotechnology Grade (1st Base), RT PCR Grade Water (Applied Biosystems), loading dye (Geneaid), 10x Tris Borate EDTA Buffer (1st Base), satu set primer invA, satu set primer fliC, dan Type It ${ }^{\circledR}$ HRM (Qiagen).

\section{Prosedur Kerja}

\section{Isolasi DNA bakteri target dan non-target}

Sejumlah $1 \mathrm{ml}$ kultur yang berusia 24 jam dimasukkan dalam tabung sentrifus 1,5 mL dan didiamkan dalam air mendidih selama 20 menit. Selanjutnya tabung sentrifus segera dimasukkan ke dalam freezer selama 5 menit dan disentrifus pada $12000 \mathrm{rpm}$ selama 5 menit. Supernatan dipipet dan dipindahkan ke dalam tabung sentrifus yang baru. Konsentrasi dan kemurnian DNA hasil isolasi diukur menggunakan nanopsektrofotometer dan digunakan sebagai cetakan DNA.

\section{Penetapan konsentrasi primer oligonukleotida}

Primer oligonukleotida yang digunakan dalam identifikasi Salmonella enterica serovar Typhimurium adalah invA dan flic (tabel 3). Kedua jenis primer tersebut didesain oleh IDN® (Singapura). Primer dalam bentuk padatan disuspensi dengan NFW (nuclease free water) dalam jumlah tertentu sesuai petunjuk pada label primer untuk memperoleh konsentrasi $100 \mu \mathrm{M}$.

\begin{tabular}{|c|c|c|c|}
\hline Target & Sequence $\left(5^{\prime}-3^{\prime}\right)$ & $\begin{array}{l}\text { Ukuran } \\
\text { amplikon }\end{array}$ & Referensi \\
\hline $\operatorname{invA}$ & $\begin{array}{l}\text { Forward: } \\
\text { ATCAGTACCAGTCGTCTTATCTTGAT } \\
\text { Reverse: } \\
\text { TCTGTTTACCGGGCATACCAT }\end{array}$ & 211 & $\begin{array}{c}\text { Shanmuga- } \\
\text { sundaram, } \\
2009(8)\end{array}$ \\
\hline flic & $\begin{array}{l}\text { Forward: } \\
\text { ATAGCCATCTTTACCAGTTCCCCC } \\
\text { Reverse: } \\
\text { GCTGCAACTGTTACAGGATATGCC }\end{array}$ & 183 & $\begin{array}{l}\text { Lim et.al, } \\
2003 \text { (9) }\end{array}$ \\
\hline
\end{tabular}

Untuk eksperimen menggunakan instrumen PCR konvensional, primer invA digunakan pada konsentrasi 300 $\mathrm{nM}$, merujuk pada penelitian yang telah dilakukan sebelumnya (8). Sedangkan primer fliC digunakan pada konsentrasi $800 \mathrm{nM}$, merujuk pada Protokol Deteksi Bakteri Patogen yang dikeluarkan oleh Badan POM tahun 2014 (10). Kedua konsentrasi primer tersebut sesuai dengan nilai konsentrasi primer yang direkomendasikan pada protokol Go-Taq ${ }^{\circledR}$ Green Master Mix yaitu berada di rentang 100$1000 \mathrm{nM}$. Kontrol running dilakukan pada setiap konsentrasi.
Konsentrasi primer untuk Real-Time PCR ditentukan melalui optimasi berdasarkan protocol Power ${ }^{\mathrm{TM}}$ Up SYBR $^{\mathrm{TM}}$ Green Master Mix yaitu 300-800 nM. Kontrol running dilakukan terhadap konsentrasi primer yang dipilih.

\section{Uji spesifitas}

Uji spesifisitas dilakukan dengan menggunakan bakteri kontrol negatif meliputi uji inclusiviti terhadap Salmonella Enteritidis ATCC13076, dan uji exclusiviti terhadap, Escherichia coli ATCC 25922, Staphylococcus aureus ATCC 25922, Listeria monocytogenes ATCC 7644, Shigella sonnei ATCC 9290, dan Bacillus subtilis ATCC 6633.

\section{Uji sensitifitas}

Uji sensitifitas dilakukan terhadap konsentrasi DNA hasil isolasi dengan menggunakan pengenceran konsentrasi DNA $50 \mathrm{ng} ; 5 \mathrm{ng}$; 0,5 ng; 0,05 ng; 5 pg; 0,5 pg; 0,05 pg, 5 fg; 0,5 fg dan dilanjutkan dengan amplifikasi menggunakan metode PCR. Limit deteksi pada PCR konvensional ditetapkan berdasarkan nilai konsentrasi DNA terendah yang masih menghasilkan pita pada gel elektroforesis. Sedangkan pada real-time PCR, nilai limit deteksi ditentukan berdasarkan konsentrasi DNA terendah yang mengalami amplifikasi.

\section{Penyiapan bakteri uji}

Perhitungan jumlah mikroba target Salmonella typhimurium dilakukan dengan metode Angka Lempeng Total dengan menggunakan media Plate Count Agar dan kondisi inkubasi $37^{\circ} \mathrm{C}$ selama 24 jam (11). Konsentrasi inokulum yang akan digunakan sebagai cemaran adalah $10^{3} \mathrm{koloni} / \mathrm{ml}$ (12).

Satu ose bakteri uji ditumbuhkan pada media cair BHIB dan diinkubasi selama 24 jam pada suhu optimum. Bakteri umur 24 jam diencerkan dalam $9 \mathrm{~mL}$ larutan $\mathrm{NaCl} 0,9 \%$ hingga konsentrasi tertentu, dan dihitung jumlah bakteri pada media PCA dengan metode tuang. Tahap ini diulang sebanyak 3 kali, kemudian dihitung nilai rata-rata.

\section{Penyiapan sampel}

Sampel yang digunakan adalah sampel pangan siap saji. Sampel dipilih berdasarkan tingkat kemungkinan kontaminasi bakteri Salmonella yaitu daging olahan, daging unggas olahan, dan salad buah. Uji pendahuluan yang dilakukan yaitu: (a) Uji organoleptis. Pemeriksaan terhadap warna, bau dan rasa; (b) Uji kualitatif $S$. Typhimurium. Pengujian menggunakan metode kultur untuk mendeteksi adanya cemaran $S$. Typhimurium dalam sampel.

Jika uji organoleptis memberikan hasil yang normal, dan uji kualitatif $S$. Typhimurium adalah negatif, maka sampel tersebut dipilih sebagai sampel uji dan dicemari bakteri $S$. Typhimurium sejumlah $10^{3} \mathrm{koloni} / \mathrm{ml}$.

\section{Penambahan cemaran bakteri dalam sampel}

Sampel ditimbang sejumlah $150 \mathrm{~g}$ dan ditambahkan $150 \mathrm{ml}$ BPW, lalu dihomogenkan dengan Stomacher ${ }^{\circledR}$. Cairan suspensi diambil dan disentrifus $1500 \mathrm{~g}$ untuk mengendapkan pengotor. Supernatan diambil sebanyak $5 \mathrm{ml}$ dalam tabung steril. Sejumlah $5 \mathrm{ml}$ bakteri uji dengan konsentrasi $10^{3} \mathrm{koloni} / \mathrm{ml}$ diinokulasikan ke dalam sampel. Sampel yang sudah diinokulasi, kemudian diinkubasi selama 1 jam pada suhu optimumnya sehingga memberi waktu pada bakteri untuk menempel pada matriks pangan. Tahap berikutnya pengenceran dilakukan dengan mengambil larutan sampel sebanyak masing-masing $1 \mathrm{ml}$ lalu dimasukkan ke dalam tabung yang sudah berisi 9 mL larutan pengencer BPW dan diinkubasi pada suhu $37{ }^{\circ} \mathrm{C}$ selama 24 jam. Pada tahap akhir, $1 \mathrm{ml}$ sampel diambil dan dilanjutkan ke prosedur isolasi DNA. 


\section{Isolasi DNA bakteri pada sampel pangan}

Satu ml kultur yang berusia 24 jam disentrifus dengan kecepatan 13.000-16.000 x g selama 2 menit dan supernatan dibuang menyisakan pellet bakteri pada dasar tabung mikrosentrifus. Pellet tersebut selanjutnya diproses menggunakan Wizard ${ }^{\circledR}$ Genomic DNA Purification Kit (Promega) sesuai dengan protokol yang disarankan. Secara ringkas, $600 \mu \mathrm{L}$ nuclei lysis solution ditambahkan ke pellet bakteri dan diinkubasi pada suhu $80{ }^{\circ} \mathrm{C}$ selama 5 menit. Campuran didinginkan sampai suhu ruang lalu $3 \mu \mathrm{L}$ RNase solution ditambahkan pada campuran, dihomogenkan, diinkubasi pada suhu $37^{\circ} \mathrm{C}$ selama $15-60$ menit, dan didinginkan sampai suhu ruang. Selanjutnya, $200 \mu \mathrm{L}$ protein precipitation solution ditambahkan ke dalam campuran kemudian divorteks. Campuran diinkubasi dalam es selama 5 menit kemudian disentrifus dengan kecepatan 13.000 16.000 x g selama 3 menit. Supernatan dipindahkan ke dalam tube yang berisi $600 \mu \mathrm{L}$ isopropanol pada suhu ruang. Campuran disentrifus kemudian supernatan dibuang. Sebanyak $600 \mu \mathrm{L}$ etanol $70 \%$ ditambahkan pada suhu ruang dan disentrifus dengan kecepatan 13.000-16.000 selama 2 menit. Etanol diuapkan dan pellet dikeringkan pada udara terbuka selama 10-15 menit. Pellet DNA direhidrasi dengan $100 \mu \mathrm{L}$ rehydration solution selama 1 jam pada suhu $65^{\circ} \mathrm{C}$ Konsentrasi dan kemurnian DNA hasil isolasi diukur menggunakan nanospektrofotometer.

Deteksi S. Typhimurium menggunakan PCR konvensional

Sampel DNA terlebih dahulu dianalisis menggunakan metode PCR konvensional pada alat thermal cycler PCR 7500 (Applied Biosystem) berdasarkan protokol GoTaq ${ }^{\circledR}$ Green Master Mix (Promega). Konsentrasi primer invA dan primer fliC dalam tiap reaksi dengan total volume $25 \mu \mathrm{L}$ adalah berturut-turut sebesar $300 \mathrm{nM}$ (8) dan $800 \mathrm{nM} \mathrm{(10)}$ Tahapan reaksi dimulai dengan denaturasi awal pada suhu $95^{\circ} \mathrm{C}$ selama 3 menit kemudian dilanjutkan dengan 30 siklus yang terdiri dari denaturasi (denaturation) pada suhu $95^{\circ} \mathrm{C}$ selama 1 menit, penempelan (annealing) pada suhu $65^{\circ} \mathrm{C}$ selama 1 menit, dan pemanjangan (extension) pada suhu $72^{\circ} \mathrm{C}$ selama 30 detik. Setelah itu dilanjutkan dengan pemanjangan akhir (final extension) pada suhu $72^{\circ} \mathrm{C}$ selama 1 menit (9). Produk PCR kemudian diproses menggunakan $2 \%$ gel agarosa dan divisualisasikan menggunakan perangkat GelDoc ${ }^{\mathrm{TM}}$ XRT Imaging System.

Deteksi S. Typhimurium Menggunakan real-time PCR dan melt curve analysis

Sampel DNA selanjutnya dianalisis menggunakan alat Real Time PCR 7500 (Applied Biosystem) berdasarkan protokol Power up SYBR Green (Applied Biosystem). Konsentrasi primer invA dan primer fliC dalam tiap reaksi dengan total volume $20 \mu \mathrm{L}$ adalah berturut-turut sebesar $300 \mathrm{nM}$ dan 500 nM. Reaksi amplifikasi dimulai dengan denaturasi awal pada suhu $95^{\circ} \mathrm{C}$ selama 10 menit kemudian dilanjutkan dengan 40 siklus yang terdiri dari dua tahap yaitu denaturasi pada suhu $95^{\circ} \mathrm{C}$ selama 15 detik dan inkubasi pada suhu $60^{\circ} \mathrm{C}$ selama 1 menit untuk proses annealing dan extension. Setelah itu dilanjutkan dengan analisis kurva lebur (melt curve analysis) terhadap produk amplifikasi dengan peningkatan suhu sebesar $1^{\circ} \mathrm{C}$ secara bertahap dari $60^{\circ} \mathrm{C}$ sampai $95^{\circ} \mathrm{C}\left( \pm 0,6^{\circ} \mathrm{C} / 20\right.$ detik $)(13)$.

Deteksi S. Typhimurium menggunakan high resolution melting

Untuk metode high resolution melting (HRM), sampel DNA diproses menggunakan alat Rotor Gene Q (Qiagen) berdasarkan protokol Type It@ HRM (Qiagen). Secara ringkas, sampel DNA terlebih dahulu diamplifikasi menggunakan primer invA (konsentrasi akhir $300 \mu \mathrm{M}$ ) dalam tiap reaksi dengan total volume $20 \mu \mathrm{L}$. Amplifikasi produk dilakukan dengan tahapan denaturasi awal $95^{\circ} \mathrm{C}$ selama 5 menit kemudian dilanjutkan dengan 40 siklus yang terdiri atas denaturasi pada $94^{\circ} \mathrm{C}$ selama 10 detik, annealing pada $60^{\circ} \mathrm{C}$ selama 30 detik, dan ekstensi pada $72^{\circ} \mathrm{C}$ selama 10 detik. Pada tahap akhir kemudian dilakukan analisis suhu lebur resolusi tinggi (high resolution melting analysis, HRMA) terhadap produk amplifikasi dengan peningkatan suhu sebesar $0.1^{\circ} \mathrm{C}$ secara bertahap dari $50^{\circ} \mathrm{C}$ sampai $99^{\circ} \mathrm{C}$ $\left( \pm 0,1^{\circ} \mathrm{C} / 2\right.$ menit $)$.

\section{HASIL DAN PEMBAHASAN}

\section{Spesifisitas deteksi S. Typhimurium menggunakan PCR konvensional sangat bergantung pada gen target}

Pada penelitian ini, kami melakukan uji eksklusifiti dan uji inklusifiti untuk menentukan spesifisitas sampel berdasarkan gen target yang digunakan. Uji eksklusifiti menggunakan lima jenis bakteri non-target yaitu Escherichia coli ATCC 25922, Staphylococcus aureus ATCC 25922, Listeria monocytogenes ATCC 7644, Shigella sonnei ATCC 9290, dan Bacillus cereus ATCC 6633. Sedangkan uji eksklusifiti menggunakan bakteri Salmonella dengan serotipe yang berbeda, yaitu S. Enteritidis ATCC 13076. Adapun gen target yang digunakan dalam penelitian ini adalah invA dan fliC.

Uji spesifisitas primer invA menggunakan PCR konvensional memperlihatkan adanya amplifikasi pada bakteri $S$. Typhimurium dan $S$. Enteritidis, dan tidak memperlihatkan amplifikasi pada lima spesies bakteri nontarget lainnya (Gambar 1), mengindikasikan bahwa sekuens target invA hanya dimiliki oleh strain Salmonella yang diuji dalam peneitian ini. Hal tersebut sejalan dengan hasil yang dilaporkan sebelumnya (8). Akan tetapi, pita DNA yang terdeteksi pada $S$. Typhimurium terletak sejajar dengan pita DNA yang terdeteksi pada $S$. Enteritidis (Gambar 1), menandakan bahwa pita DNA hasil amplifikasi dari kedua Salmonella tersebut memiliki panjang amplikon yang serupa sehingga metode PCR konvensional tidak dapat membedakan kedua Salmonella tersebut menggunakan sekuens target invA.

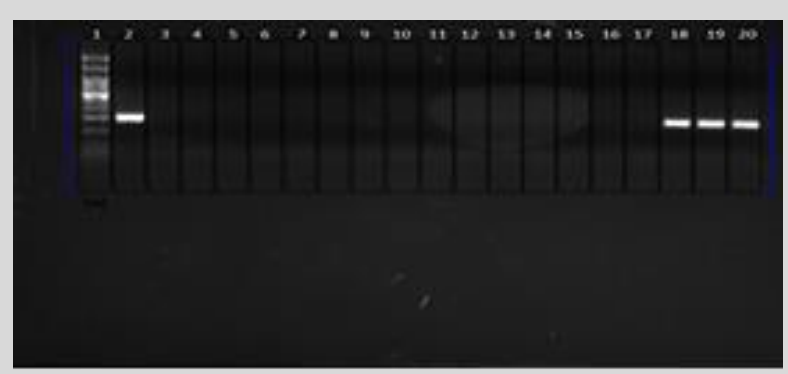

Gambar 1. Uji spesifisitas primer invA menggunakan PCR konvensional (Lajur 1. Marker DNA Ladder 100 bp; Lajur 2. Kontrol positif Salmonella Typhimurium; Lajur 3-5. Staphylococcus aureus; Lajur 6-8. Escherichia coli; Lajur 9-11. Listeria monocytogenes; Lajur 12-14. Shigella sonnei; Lajur 15-17. Bacillus cereus; Lajur 18-20. Salmonella Enteritidis)

Berikutnya kami menguji spesifisitas primer fliC. Primer ini mengamplifikasi sekuens gen target fliC yang mengkode ekspresi flagellin pada bakteri. Seperti yang terlihat pada Gambar 2, amplifikasi hanya terjadi pada sampel DNA dari bakteri $S$. Typhimurium, dan tidak terjadi pada sampel DNA $S$. Enteritidis maupun bakteri-bakteri uji lainnya. Hal ini menunjukkan bahwa fliC merupakan gen target yang bersifat lebih spesifik, jika dibandingkan dengan invA, untuk digunakan dalam mendeteksi keberadaan $S$. Typhimurium. Penelitian yang dilakukan oleh (14), memperlihatkan bahwa 
selain terdeteksi pada $S$. Typhimurium, fliC juga terdeteksi pada $S$. Aberdeen dan $S$. Landau. Tetapi karena keterbatasan strain Salmonella yang terdapat di laboratorium, maka pengujian terhadap kedua strain Salmonella tersebut tidak dapat dilakukan.

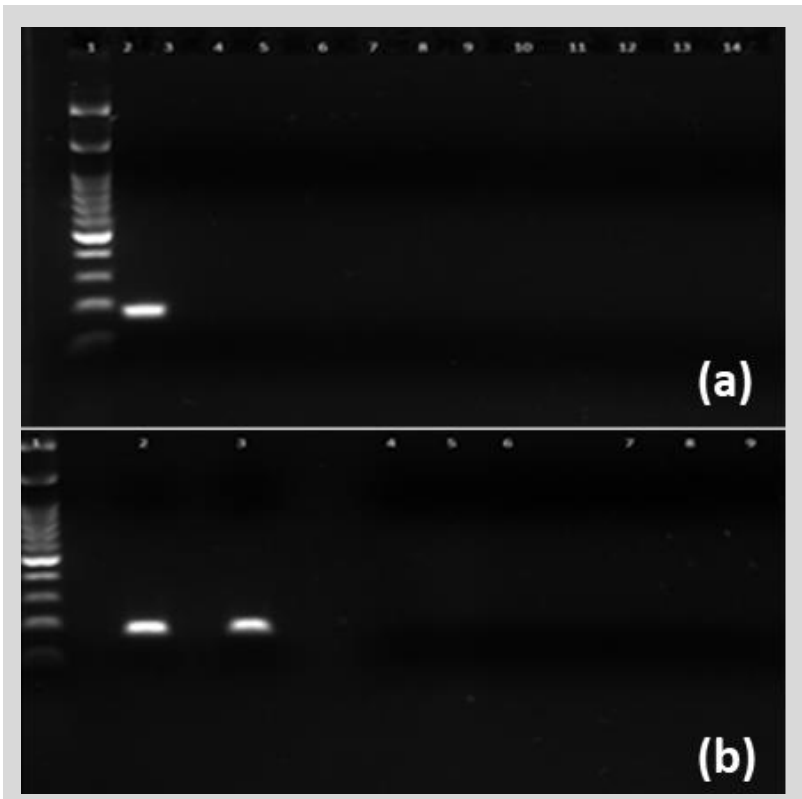

Gambar 2. (a) Uji spesifisitas primer flic menggunakan PCR konvensional (Lajur 1. Marker DNA Ladder 100 bp; Lajur 2. Kontrol positif Salmonella Typhimurium; Lajur 3-5. Salmonella Enteritidis; Lajur 6-8. Escherichia coli; Lajur 9-11. Listeria monocytogenes; Lajur 12-14. Staphylococcus aureus). (b) Uji spesifisitas primer flic menggunakan PCR konvensional (Lajur 1. Marker DNA Ladder 100 bp; Lajur 2-3 Kontrol positif Salmonella Typhimurium; Lajur 4-6. Shigella sonnei; Lajur 7-9. Bacillus cereus)

Uji spesifisitas primer invA menggunakan real-time PCR memberikan hasil yang serupa dengan yang diperoleh menggunakan teknik PCR konvensional. Hasil amplifikasi sekuens target menggunakan primer invA hanya terlihat pada sampel DNA $S$. Typhimurium dan $S$. Enteritidis namun tidak pada sampel DNA dari lima bakteri non-target yang digunakan (Gambar 3). Uji spesifisitas primer fliC menggunakan metode real-time PCR juga memberikan hasil yang sama dengan PCR konvensional, dimana amplifikasi hanya terjadi pada bakteri target $S$. Typhimurium (Gambar 4).

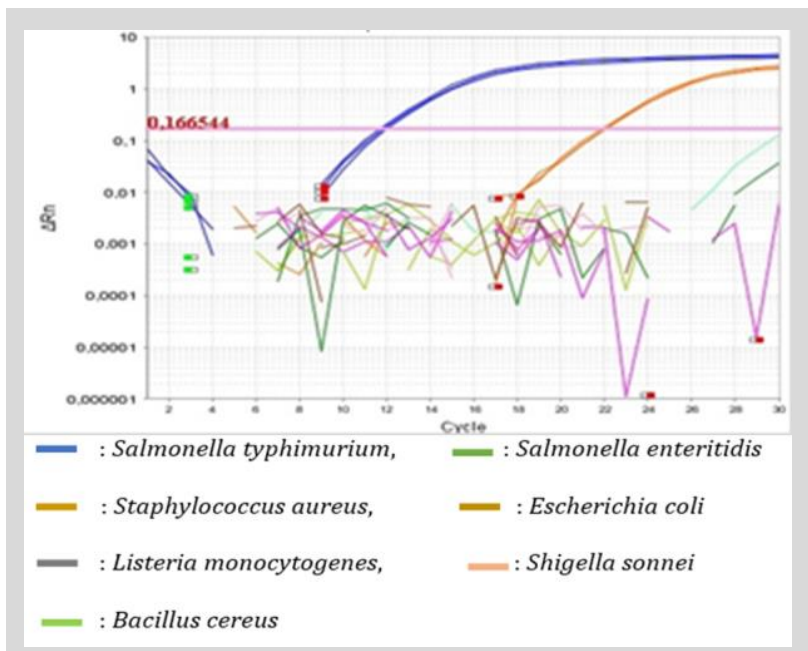

Gambar 3. Uji spesifisitas primer invA menggunakan real-time PCR

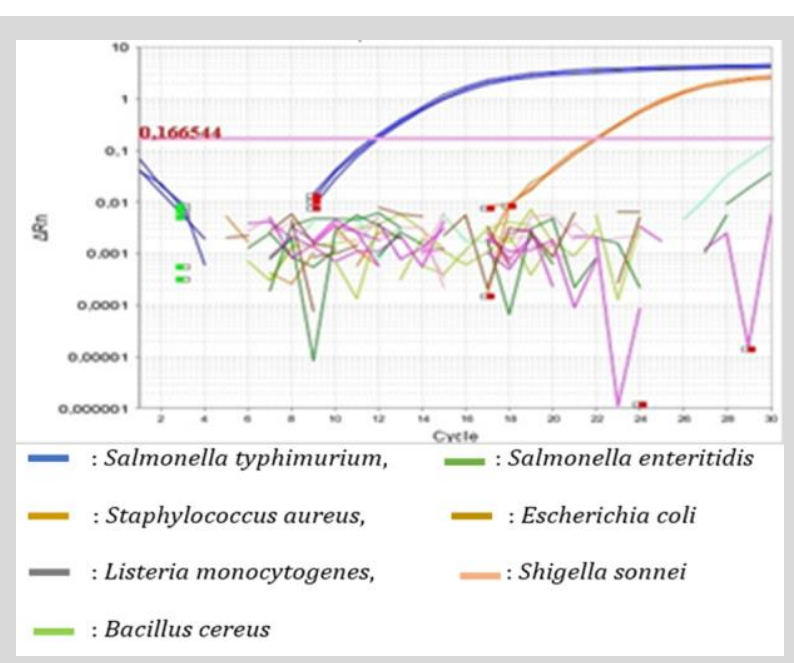

Gambar 4. Uji spesifisitas primer fliC menggunakan real-time PCR

Sensitivitas real-time PCR dalam deteksi S. Typhimurium menggunakan gen target flic

Uji sensitifitas dilakukan dengan menggunakan primer yang memberikan hasil yang spesifik yaitu fliC. Dengan menggunakan metode PCR konvensional DNA $S$. Typhimurium masih dapat dideteksi pada konsentrasi 0,5 ng (Gambar 5). Meskipun pita DNA juga terlihat pada konsentrasi dibawah $0,5 \mathrm{ng}$, akan tetapi posisinya tidak sejajar dengan pita DNA pada konsentrasi yang lebih tinggi. Kemungkinan pita tersebut adalah primer-dimer yang terjadi karena konsentrasi DNA yang sangat kecil. Nilai konsentrasi terendah yang masih bisa terdeteksi ditetapkan sebagai nilai LOD.

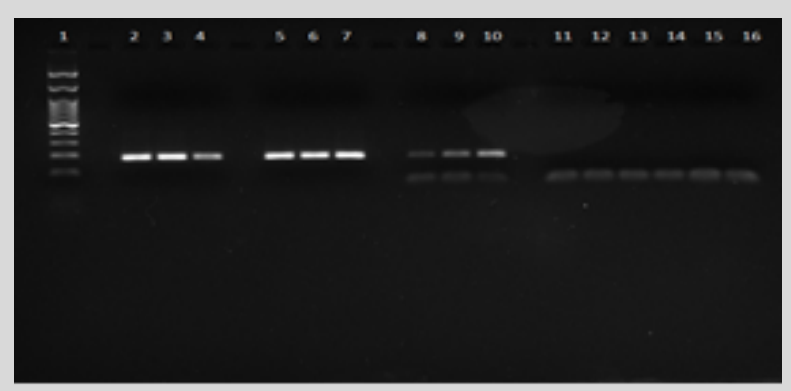

Gambar 5. Uji sensitifitas PCR konvensional (Lajur 1. Marker DNA Ladder 100 bp; Lajur 3-5. DNA konsentrasi 50 ng; Lajur 7-9. DNA konsentrasi $5 \mathrm{ng}$; Lajur 11-13. DNA konsentrasi 0,5 ng; Lajur 15-17. DNA konsentrasi 0,05 ng; Lajur 18-20. DNA konsentrasi 5 pg

Uji sensitifitas juga dilakukan menggunakan real-time PCR 7500 (Applied Biosystem) menggunakan primer fliC. Nilai limit deteksi yang diperoleh jauh lebih kecil dari pada PCR konvensional, yaitu 0,5 pg (Gambar 6). Hal ini menunjukkan bahwa dalam penelitian ini instrumen real-time PCR memberikan hasil yang lebih sensitif dibanding PCR konvensional karena masih dapat mendeteksi keberadaan DNA $S$. Typhimurium meskipun dalam jumlah yang sangat kecil. Pada hasil uji spesifisitas primer invA terdapat dua kurva amplifikasi yaitu pada bakteri $S$. Typhimurium dan $S$. Enteritidis. Untuk membedakan keduanya maka dilakukan analisis melt curve. Dari hasil analisis melt curve diperoleh nilai melting temperature (Tm) yang sama antara keduanya. Nilai $\mathrm{Tm} S$. Typhimurium adalah $\pm 83,72^{\circ} \mathrm{C}$ dan $S$. Enteritidis adalah $\pm 83,14^{\circ} \mathrm{C}$. Kurva yang dihasilkan pun sangat identic sehingga menyulitkan karakterisasi. Berdasarkan hasil tersebut dapat dikatakan bahwa dalam penelitian ini metode analisis melt curve tidak dapat digunakan untuk 
membedakan $S$. Typhimurium dari $S$. Enteritidis jika menggunakan primer invA (Gambar 7).
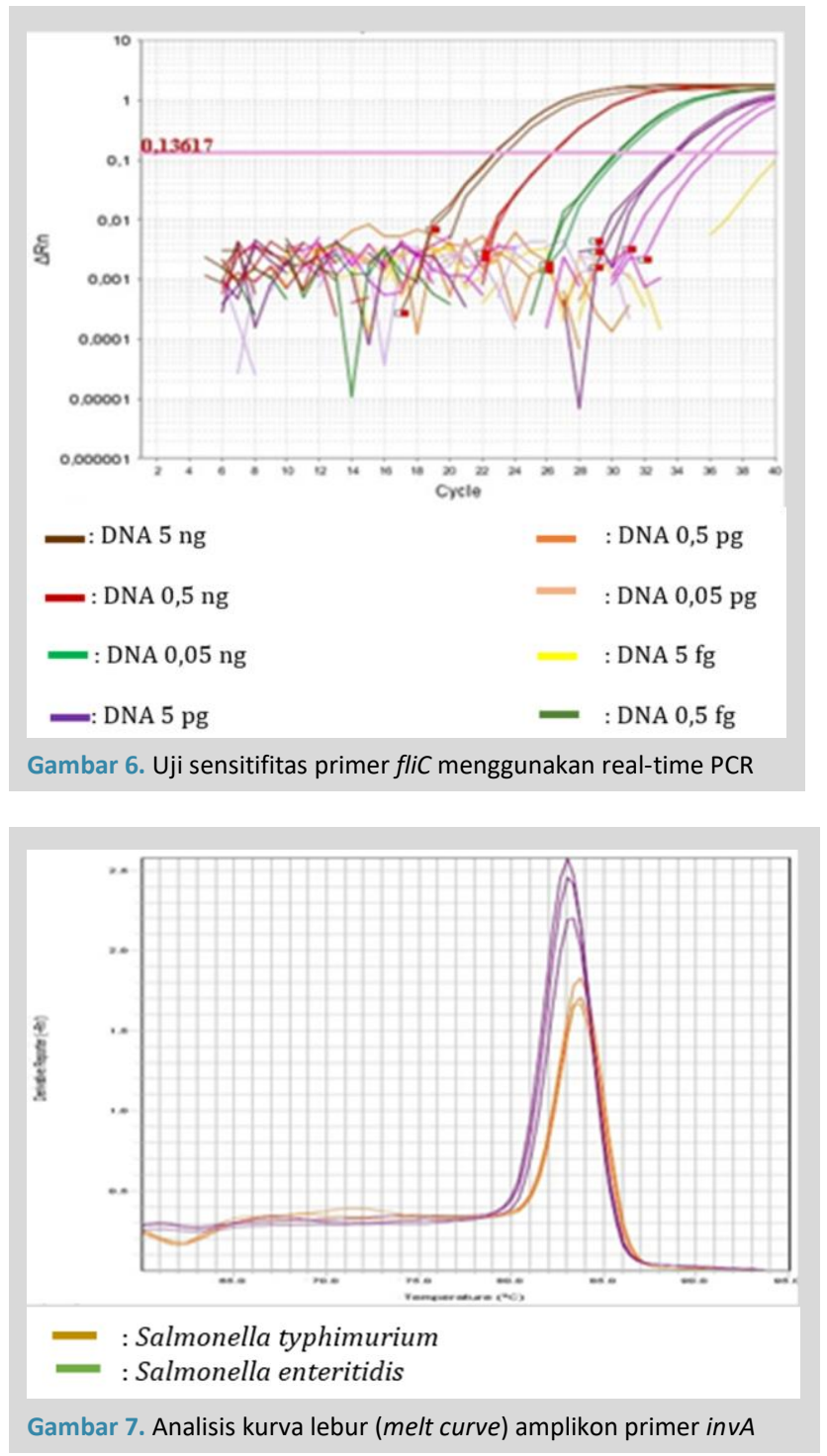

Selektifitas deteksi S. Typhimurium menggunakan teknik high resolution melting

Analisis kurva lebur (melt curve) merupakan metode yang cepat dan murah untuk memeriksa spesifisitas primer dan sekuens gen target. Sayangnya, analisis melt curve tidak dapat digunakan untuk membedakan $S$. Typhimurium dari $S$. Enteritidis dalam penelitian ini jika menggunakan primer invA (Gambar 7). Dengan demikian, dibutuhkan metode alternatif lain yang juga cepat dan murah. Metode genotyping Salmonella spp berbasis HRM (high resolution melting) adalah metode yang sangat cepat, tangguh, dan mudah diinterpretasi (7). Dalam penelitian ini metode analisis HRM digunakan pada instrumen Rotor Gene Q (Qiagen) dan data yang diperoleh dianalisis menggunakan Rotor Gene Q series software ver.2.0.2 (Gambar 8).

Berdasarkan profil nilai Tm dan profil denaturasi yang diperoleh (Gambar 8), dapat disimpulkan bahwa metode HRM dapat digunakan untuk membedakan $S$. Typhimurium dari $S$. Enteritidis meskipun menggunakan primer invA. Profil denaturasi DNA dipengaruhi oleh komposisi basa sekuens DNA target yang berbeda pada setiap spesies. Hasil yang diperoleh sejalan dengan penelitian yang dilakukan oleh (7), dimana analisis HRM dapat membedakan serotipe Salmonella dengan menggunakan beberapa gen target.

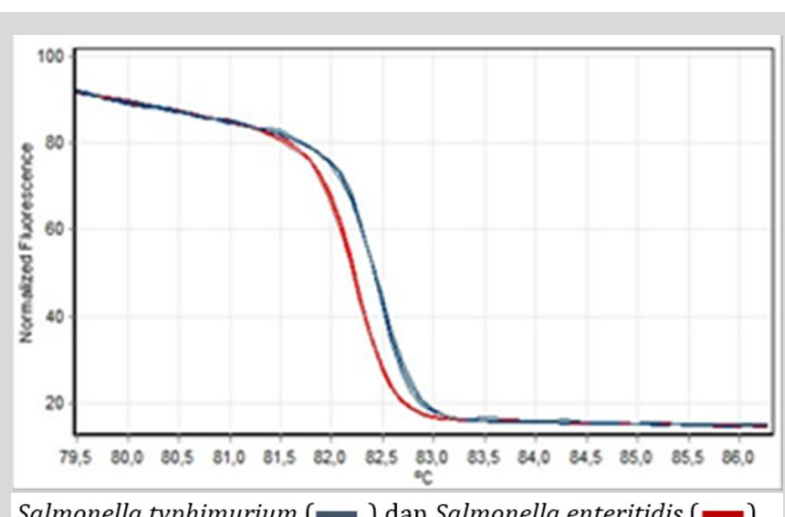

Salmonella typhimurium ( $(-)$ ) dan Salmonella enteritidis (

Gambar 8. Hasil analisis HRM memperlihatkan perbedaan profil melting temperature (Tm) dari S. Typhimurium dan S. Enteritidis.

\section{Deteksi S. Typhimurium pada produk pangan siap saji}

Selanjutnya, kami akan menggunakan metode yang telah kami kembangkan untuk mendeteksi keberadaan $S$. Typhimurium di dalam sejumlah produk pangan siap saji. Tiga jenis produk pangan siap saja yang diuji di dalam penelitian ini adalah produk olahan daging, produk olahan ayam, dan produk berupa salad buah.

Uji pendahuluan menunjukkan ketiga jenis pangan tersebut berada dalam kondisi normal. Hasil uji kualitatif memperlihatkan bahwa sampel tidak mengandung Salmonella. Ini dilihat dari koloni yang tumbuh pada sampel tidak sama dengan koloni spesifik $S$. Typhimurium pada media XLD (koloni translusen dengan bintik hitam di tengah) (Tabel 2 dan Gambar 9). Ketiga jenis pangan tersebut memenuhi syarat untuk dijadikan sampel dalam penelitian ini. Tahap selanjutnya adalah menambahkan cemaran bakteri $S$. Typhimurium ke dalam masing-masing sampel dengan konsentrasi $10^{3} \mathrm{koloni} / \mathrm{ml}$.

\begin{tabular}{|c|c|c|c|c|}
\hline No. & Sampel & & Parameter & \\
\hline 1 & $\begin{array}{l}\text { Olahan } \\
\text { Daging }\end{array}$ & $\begin{array}{l}\text { Campuran } \\
\text { daging dalam } \\
\text { kuah berwarna } \\
\text { coklat } \\
\text { kehitaman }\end{array}$ & Normal & Normal \\
\hline 2 & Olahan Ayam & $\begin{array}{l}\text { Campuran } \\
\text { Ayam Sawir } \\
\text { dan Sayuran }\end{array}$ & Normal & Normal \\
\hline 3 & Salad Buah & $\begin{array}{l}\text { Campuran } \\
\text { Potongan } \\
\text { Buah dan } \\
\text { Cairan } \\
\text { Mayonais }\end{array}$ & Normal & Normal \\
\hline
\end{tabular}

Proses selanjutnya adalah isolasi DNA dari sampel uji. Berbeda dengan prosedur isolasi DNA bakteri uji yang telah dilakukan sebelumnya, metode pendidihan tidak berhasil digunakan untuk mengisolasi DNA bakteri pada produk pangan. Isolat yang diperoleh dan digunakan sebagai cetakan (template) DNA dalam proses PCR tidak mengalami amplifikasi. Kemungkinan hal ini disebabkan karena produk pangan siap saji mengandung berbagai macam senyawa seperti lemak, protein, dan karbohidrat. Matriks yang kompleks tersebut dapat menghalangi proses isolasi DNA bakteri. Untuk mengatasi hal tersebut maka digunakan Wizard Genomic DNA Purification Kit ${ }^{\circledR}$ (Promega). Kit ini telah dilengkapi dengan berbagai pereaksi dan menghasilkan isolat DNA dengan kemurnian yang lebih baik (data tidak ditampilkan) 


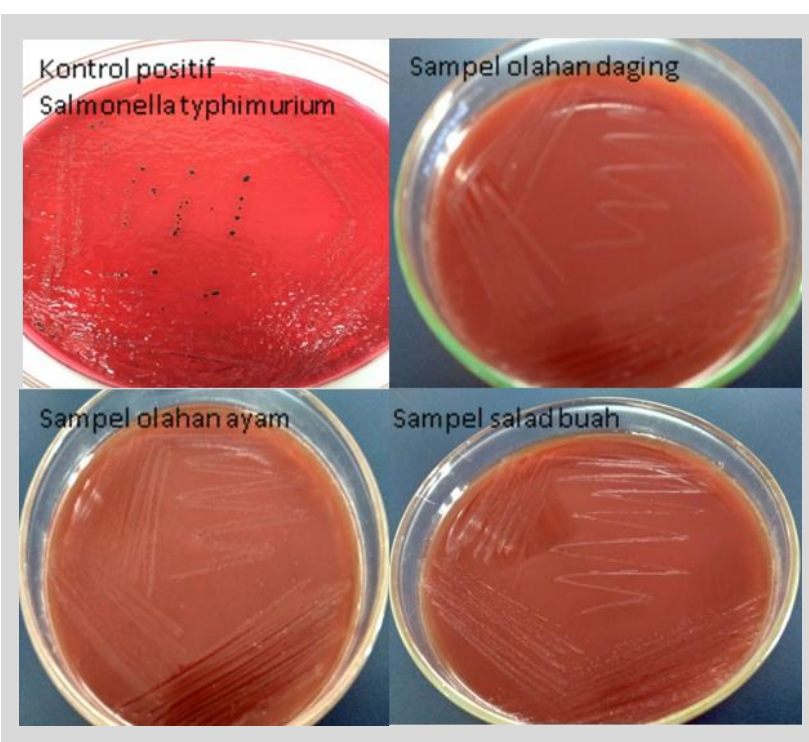

Gambar 9. Hasil uji kualitatif $S$. Typhimurium pada sampel produk pangan siap saji

Berdasarkan hasil uji spesifisitas yang telah dilakukan sebelumnya, terlihat bahwa primer invA tidak memberikan hasil yang spesifik terhadap $S$. Typhimurium menggunakan metode PCR konvensional. Oleh karena itu, primer fliC digunakan untuk mendeteksi $S$. Typhimurium dalam sampel produk pangan siap saji (Gambar 10). Primer fliC juga digunakan untuk mendeteksi $S$. Typhimurium pada produk pangan siap saji menggunakan metode real-time PCR (Gambar 11-Gambar 13).

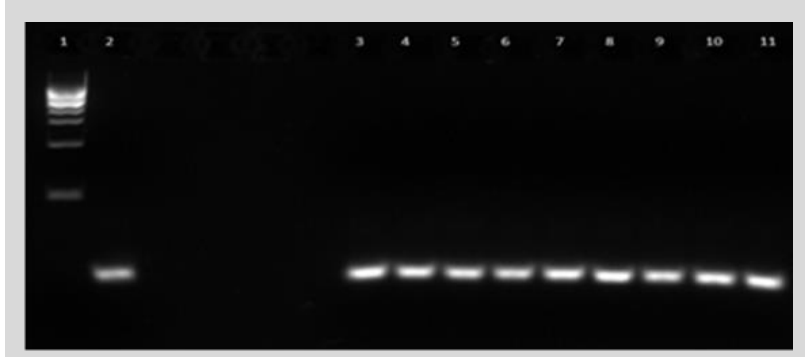

Gambar 10. Deteksi S. Typhimurium pada produk pangan olahan menggunakan PCR konvensional (Lajur 1. Marker DNA Ladder 100 bp; Lajur 2. Kontrol positif S. Typhimurium; Lajur 3-5. Sampel olahan daging; Lajur 6-8. Sampel olahan ayam; Lajur 9-11. Sampel salad buah)

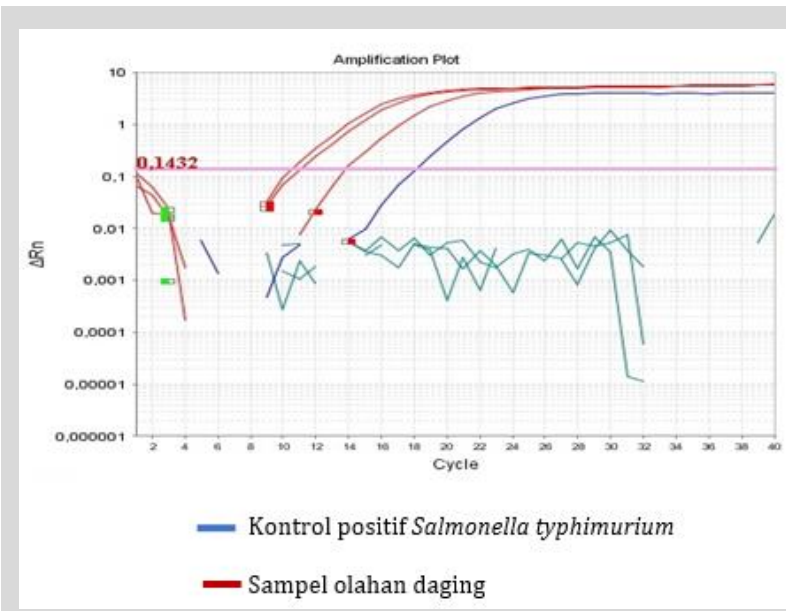

Gambar 11. Kurva amplifikasi hasil uji deteksi S. Typhimurium pada produk pangan olahan daging menggunakan metode real-time PCR

Dalam penelitian ini metode PCR konvensional dan real-time PCR dengan program analisis melt curve dapat digunakan untuk mendeteksi $S$. Typhimurium yang terdapat dalam sampel menggunakan primer fliC. Sampel pangan siap saji yang digunakan yaitu olahan daging, olahan ayam, dan salad buah. Ketiga jenis sampel tersebut memiliki komposisi dan matriks yang kompleks. Pemilihan metode isolasi DNA dan primer yang digunakan merupakan faktor yang penting dalam proses ini.

Analisis $H R M$ yang digunakan dalam penelitian ini juga memperlihatkan kinerja yang baik. Berdasarkan pengujian kultur murni menggunakan primer invA, metode HRM terbukti berhasil membedakan secara jelas antara $S$. Typhimurium dan $S$. Enteritidis, dimana hal ini tidak dapat dilakukan menggunakan hasil yang diperoleh dari PCR konvensional dan analisis melt curve.

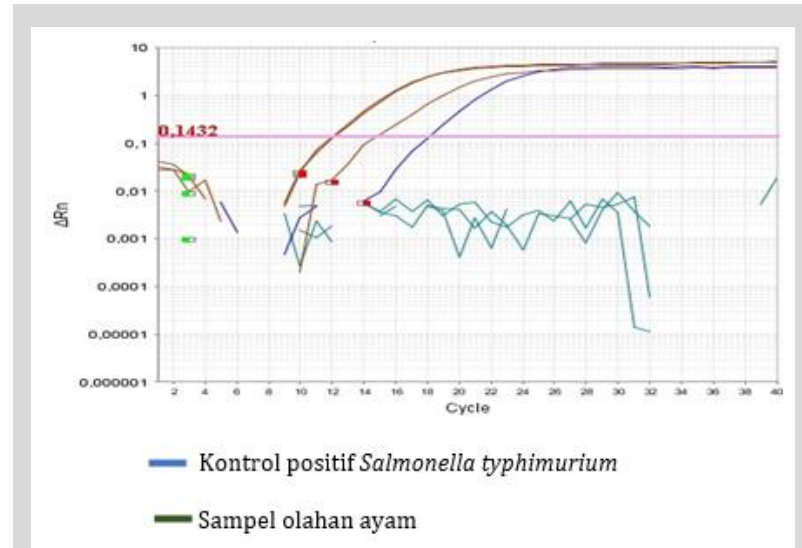

Gambar 12. Kurva amplifikasi hasil uji deteksi S. Typhimurium pada produk pangan olahan ayam menggunakan Real Time PCR

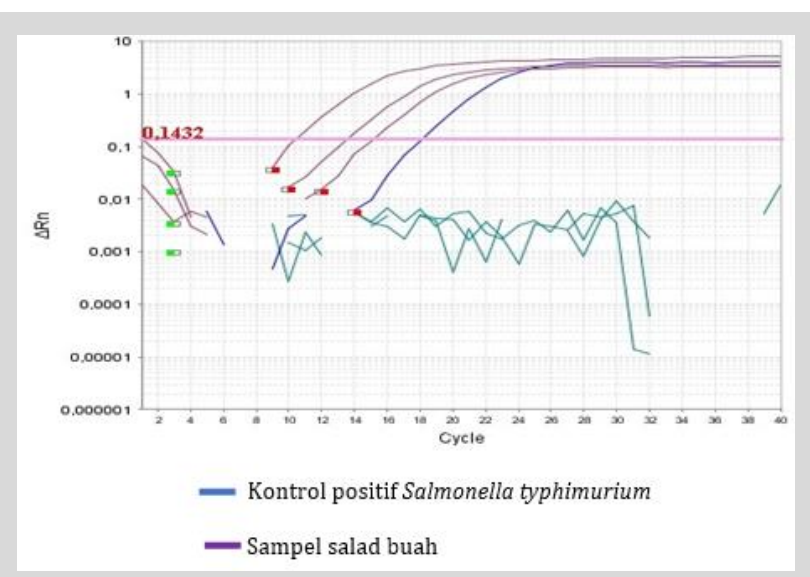

Gambar 13. Kurva amplifikasi hasil uji deteksi $S$. Typhimurium pada produk pangan salad buah menggunakan real-time PCR

\section{KESIMPULAN}

Pada penelitian ini diperoleh hasil bahwa metode deteksi Salmonella enterica serovar Typhimurium dalam produk pangan siap saji ditentukan oleh proses isolasi dan sekuens gen target yang digunakan. Metode PCR konvensional dan analisis melt curve hanya bisa mendeteksi $S$. Typhimurium dalam produk pangan siap saji jika menggunakan gen target spesifik spesies, fliC, sedangkan metode analisis HRM dapat mendeteksi $S$. Typhimurium dan membedakannya dari bakteri lain yang berbeda spesies maupun dalam satu spesies meskipun menggunakan get target invA yang kurang spesifik.

\section{UCAPAN TERIMA KASIH}

Penulis mengucapkan terima kasih kepada Badan POM RI atas segala dukungan yang diberikan. Penulis juga berterima kasih kepada Fakultas Farmasi Universitas Hasanuddin atas dukungan moril dan sarana selama penulis melakukan penelitian. 


\section{DAFTAR PUSTAKA}

1. Scallan, E. et al. Foodborne Illness Acquired in the United States-Major Pathogens. Emerging Infectious Diseases. 2011. Vol. 17. 7.

2. Badan POM RI, 2016. Laporan Tahunan Badan POM tahun 2015, Badan POM

3. WHO,2018. Salmonella. http://www.who.int/foodsafety/areas_work/ foodborne-diseases. Diunduh tanggal 12-01-2018

4. Dodd, C., Aldsworth,T., Stein, R. et al. 2017. Foodborne Disease. Third Edition. Academic Press. London. 3, 14-17.

5. Campos,G.L., Suarez J.V., Urda, M.A., Alonso, V.L. 2012 Microarray Detection and Characterization of Bacterial Foodborne Pathogens. Briefs in Food, Health, and Nutrition. 13

6. Cheng, C.M., Doran,T., Lin,W. 2015. Interlaboratory Validation for a RealTime PCR Salmonella Detection Method Using the ABI 7500 FAST RealTime PCR System. Journal of Food Protection. Vol. 78. 1119-1124

7. Bratchikov, M., Mauricas, M. 2011. Development of a multiple-run highresolution melting assay for Salmonella spp. Genotyping HRM application for Salmonella spp. subtyping. Diagnostic Microbiology and Infectious Disease 71. 192-200.

8. Shanmugasundaram,M., Radhika,M., Murali,H.S., Batra,H.V. 2009. Detection of Salmonella enterica serovar Typhimurium by selective amplification of $f l i C, f l j B$, iroB, invA, rfbJ,STM2755, STM4497 genes by polymerase chain reaction in a monoplex and multiplex format. World $J$ Microbiol Biotechnol. 1385-1394

9. Lim, Y.H.,Hirose, K.,Izumiya, H., Arakawa, E., Takahashi,H., Terajima J., Itoh,K.I., Tamura, K., Kim, S.I., Watanabe, H. 2003. Multiplex polymerase chain reaction for selective detection of Salmonella enterica Serovar Typhimurium. Japan Journal Infect. Dis. Vol. 56. 151-155.

10. Badan POM RI, 2014. Protokol deteksi E.coli patogen, S.typhimurium, dan V.cholerae dengan menggunakan multiplex PCR untuk kajian mikrobiologi es dan minuman es. PROM Badan POM RI. 1-9

11. Badan POM RI, 2003. Buku Validasi Mikrobiologi. Pusat Pengujian Obat dan Makanan Nasional., Badan POM RI, 9

12. FDA, 2015. Guidelines for the Validation of Analytical Methods for the Detection of Microbial Pathogens in Foods and Feeds. 2nd Edition. US Food \& Drug Administration Office of Foods and Veterinary Medicine.

13. Barbau-Piednoir E. Botteldoorn., Yde M., Mahillon J., Roosens N.H. 2013. Development and validation of qualitative SYBR $®$ Green real-time PCR for detection and discrimination of Listeria spp. and Listeria monocytogenes. Appl Microbiol Biotechnol 97(9):4021-4037

14. Lee.K.M., Runyon,M., Herrman,T.J., Phillips,R., Hsieh, J. 2015. Review of Salmonella detection and identification methods: Aspects of rapid emergency response and food safety. Food Control. Vol. 47. 264-276. 